\title{
European Union and online platforms in global audiovisual politics and economy: Once Upon a Time in America?
}

the International Communication Gazette 0 (0) $1-23$

(C) The Author(s) 2020

Article reuse guidelines: sagepub.com/journals-permissions DOI: 10.1 177/1748048520918496 journals.sagepub.com/home/gaz

\section{Antonios Vlassis (D)}

Center for International Relations Studies, University of Liege, Liège, Belgium

\begin{abstract}
The purpose of this article is twofold: to consider whether and how the European Union has a strong influence in global audiovisual politics and economy and to analyse whether the United States keeps playing a key role in global audiovisual flows or its domination is challenged by the European Union or other countries. These two purposes are analysed in the light of the rise of global online platforms, seen as the new dominant development in the audiovisual industry. In order to understand the European Union role and influence, the article highlights three interlinked factors: European/internal audiovisual policies, market profile and foreign audiovisual diplomacy. In the end, the article examines the competition that European Union faces in the global film economy, focusing notably on the US/Hollywood, China, India and global online platforms.
\end{abstract}

\section{Keywords}

China, cultural exception, cultural policies, European Union, global film economy, Hollywood, Netflix, online platforms, trade agreements, US trade diplomacy

\section{Corresponding author:}

Antonios Vlassis, Center for International Relations Studies, University of Liege, Bât. B3I Relations internationales Quartier Agora place des Orateurs 34000 Liège I, Liège, Belgium.

Email: avlassis@uliege.be 
In January 2019, the European Union (EU) and 48 other members of the World Trade Organization (WTO) decided to start negotiations to put in place global rules on electronic commerce. On 20 May, the European Council adopted a negotiating mandate, which explicitly stressed 'the European Union and its Member States shall maintain the possibility to preserve and develop their capacity to define and implement cultural and audiovisual policies for the purposes of preserving their cultural diversity. The European Union shall not agree to rules or commitments for audiovisual services' (Council of the European Union, 2019: 4).

Indeed, the treatment of audiovisual goods and services in bilateral and multilateral trade agreements has proved one of the most controversial issues in the European governance and EU external relations. Audiovisual goods and services, oscillated between symbolic and material spheres, raise major issues for several involved actors: economic issues because audiovisual industries are a key sector in terms of growth and employment for the national economies; political issues, given that audiovisual goods and services - seen as vehicles of collective ideas, values and representations - are resources of the power of States and of their capacity to shape their international environment; finally, identity issues because cultural expressions - distributed by audiovisual industries - are usually components of national, regional or local identities and several actors are increasingly worried on cultural dominance (Thorsby, 2010). It is revealing that according to the UNESCO Institute for Statistics (2016: 11), audiovisual services are increasingly becoming the most important cultural service traded. At the same time, cinema is the sector in which most of the export and import measures are put in place (Deloumeaux, 2018: 136).

In this view, the global audiovisual politics and economy are a strategic and relevant site for analysing the international cultural influence of EU and for understanding how audiovisual sector could allow EU to build a status of international powerful actor in global cultural politics. The urgency of this topic is linked to a recent transforming evolution: the arrival of large online platforms, which represent an unprecedented change in production, distribution, broadcasting, consumption of audiovisual content (Nieborg and Poell, 2018; Vlassis et al., 2020). 'The presence of these intermediaries in the everyday lives of citizens and consumers is raising major policy issues' (Mansell, 2015: 21). Thus, innovative over-the-top (OTT) video services, such as Netflix, Amazon Prime Video, Disney+, Apple $\mathrm{TV}+$ or HBO Max are expected to have major impact on the balance of power in the global audiovisual economy (Lobato, 2018), insofar as 'platformisation entails the rise of the platform as dominant infrastructural and/or economic model in the industry' (Evens and Donders, 2018: 4).

An academic research recently offers relevant insights on the EU action in the international cultural-audiovisual affairs. It deals with key issues: the regulation of the 'trade and culture' interface and the EU's role (Psychogiopoulou, 2014; Richieri-Hanania, 2019), the EU role in the implementation of the Convention on diversity of cultural expressions (Pauwels and Loisen, 2016), the interregional cooperation related to the audiovisual sector with special focus on the links 
between EU and Mercosur (Canedo and Crusafon, 2014; Sarikakis and Ganter, 2014). The growing body of research seeks to understand the overall action of the EU in international cultural affairs. However, based on a legal-institutionalist approach, it seems to overestimate the evolving EU's influence and impact in global cultural politics and economy. In other terms, the argument here is that this research object is multidimensional and it is necessary to highlight multiple variables beyond the policy results of EU institutions.

The article that follows is analytical and its research purpose is twofold: first, to consider whether and how EU has a strong influence in global cultural politics and economy - taking as case study the audiovisual and film sector - and second, to analyse whether the United States keeps playing a key role in global audiovisual content flows or its dominance is challenged by the EU or other countries - such as China or India. And the two research purposes are analysed in the light of the rise of global online platforms, seen as the new dominant development in the audiovisual industry. In fact, in its contested position between national and supranational interests, the study of EU in global audiovisual politics and economy can be seen to mirror central debate related to future of European project, 'namely to negotiate and reconcile the desires of cultural specificity and national identity with the larger ideal of supranational community' (Bergfelder, 2005: 315).

In order to analyse the two research purposes mentioned above, the article is structured on three interlinked factors (Galperin, 1999) of the EU audiovisual policy and economy:

(i) European/internal audiovisual policies;

(ii) market profile;

(iii) foreign audiovisual diplomacy.

The first factor concerns the domestic regulatory framework for audiovisual industries within the EU. The second one refers to the distribution of economic resources among the trading partners' audiovisual industries. The third one deals with the ability of EU to promote European audiovisual content in the global marketplace and to disseminate European standards related to audiovisual sector at a global scale. Besides, the quantitative comparative data presented in the article are notably with respect to film industry in EU, US, China and India (film production, market share, box-office revenues). ${ }^{1}$ In this view, the article seeks to offer a multi-dimensional analysis for understanding the EU influence in global audiovisual politics and economy, paying special attention to the arrival of global online platforms.

To address the two research purposes, the article primarily discusses the key norms, which have dominated the global politics for audiovisual goods and services since the 1990s, highlighting specifically the link between international economic integration and audiovisual sector. It emphasises, furthermore, the evolution of the relationship between EU institutions and audiovisual industry, 
as well as on the development of EU film market since the 1990s. It also aims to draw up an inventory of EU's role within the global audiovisual politics. In the end, the article examines the competition that EU faces in the global audiovisual economy, focusing notably on the US/Hollywood, China and India.

\section{Global politics for audiovisual goods and services: The Good, the Bad and the Ugly}

Since early 1990s, the elimination of regulatory and financial measures in the audiovisual sector has been a major priority of US trade diplomacy as well as a stumbling block in the process of the international and regional economic integration (Vlassis, 2015). National government policies in support of their film industries rely on two types of measures: those that attempt to restrict entry of foreign competitors, such as tariffs and quotas, and those that provide preferential treatment to the domestic industry in the form of subsidies and tax credits (Crane, 2014: 8). 'The USA stands as the major exponent of a competition approach to the production and supply of media content' (Gibbons and Humphreys, 2012: 18). The goal of the US administration, followed mainly by several powerful industrial associations such as Motion Pictures Association of America (MPAA, 2017), was to incorporate cultural and audiovisual goods and services within the agenda of international trade negotiations. The most prominent examples are the last period of negotiations on the General Agreement on Trade in Services (GATS) of the WTO in 1993, the negotiations on the Multilateral Agreement on Investment within the Organization for Economic Cooperation and Development, as well as the North American Free Trade Agreement (NAFTA) between US, Canada and Mexico in 1994. As Miller and Yúdice (2002: 174) noted, 'The US motivation was obvious: replacing national societies of culture with a global society of alleged efficiency'. Meanwhile, since 2001 (the Doha Round) and the institutional crisis of multilateral model of the WTO, the US administration has also opted for the plurilateral and bilateral pathway, concluding free trade agreements (FTAs) with economically developed and developing countries ${ }^{2}$ and seeking to promote liberalisation of audiovisual markets as key norm (Gagné, 2016).

The US position, based on 'free trade' norm, was largely associated with the Washington consensus, which has gained ascension since the end of the Cold War and the collapse of the bipolar world order. The consensus asserts that global welfare would be maximised by the liberalisation of trade, finance and investment, and by restructuring national economies to provide an enabling environment for capital. In this regard, the assumption entails that audiovisual policies should follow an underlying principle that 'human well-being can best be advanced by liberating individual entrepreneurial freedoms and skills within an institutional framework characterized by strong private property rights, free markets, and free trade' (Harvey, 2005: 2). 
At the same time, rapid financial globalisation, international and regional economic integration and liberalisation of trade exchanges raised major concerns over the implications on cultural identities, cultural sovereignty and survival of national cultural industries. As such, a coalition of actors, driven by France and Canada and several organizations of cultural professionals, promoted the 'cultural exception' (exception culturelle) norm in order to exclude cultural and audiovisual goods and services from the agenda of trade negotiations. 'Cultural exception' norm focuses on specificity of cultural goods and services - which are not considered as simply commercial commodities bought and sold on markets -, as well as on legitimacy of public intervention in cultural and audio-visual sectors (Buchsbaum, 2017; Vlassis, 2015). Small wonder, then, that the Convention on the Protection and the Promotion of Diversity of Cultural Expressions (hereafter CDCE) adopted by UNESCO in 2005 - was seen as a response to the threat towards cultural policies coming from international and regional economic integration (Graber, 2006). As of February 2020, the CDCE has received the support of 148 member-states and of EU. The CDCE recognises the specificity of cultural goods and services and the importance of cultural policies for the protection and promotion of the diversity of cultural expressions. It also incorporates concrete provisions to the link culture and sustainable development, aiming to strengthen international cultural cooperation through various tools, such as expert and information exchange among the Parties, preferential treatment for developing countries and the setting up of the International Fund for Cultural Diversity.

In addition, the new context of platform capitalism (Srnicek, 2017) intensifies this normative confrontation, insofar as US online plarforms have been emerged as a powerful technological players in global audiovisual economy since 2010 s. In this regard, one of the key diplomacy priorities of the Obama administration was to include digital cultural services in the agenda of megaregional partnerships, such as Trans-pacific partnership (TPP) between 12 countries along the Pacific Rim $^{3}$ singed in 2016, the negotiations on Transatlantic Trade and Investment Partnership (T-TIP) between EU and US and on Trade in Services Agreement (TiSA). Indeed, the US priority was to treat online cultural services, such as video-on-demand (VOD) services into a single chapter devoted to e-commerce, to promote an open market environment and to eliminate all forms of discrimination with regard to digital cultural and audiovisual content (Guèvremont, 2015: 142). For its part, Trump administration withdrew the United States from the TPP in 2017 and the negotiations on TiSA and T-TIP are in hibernation mode. Today, the US trade diplomacy puts in place a new transactional approach, which establishes an extremely unpredictable context in international economic relations. In this view, the multilateral regulation of digital cultural and audiovisual services is expected to be tested within two current negotiations: the trade negotiations between US and China dealing with several technological sectors and the WTO ongoing negotiations on electronic commerce (Vlassis, 2018). 


\section{EU audiovisual policies and Janus-faced syndrome: Un long dimanche des fiançailles}

First, regarding the factor of regulatory framework, the EU audiovisual landscape has experienced 'a period of continuous change from the 1980s onwards' associated with changes in audiovisual policy and 'a series of technological developments, which have, either directly or indirectly, had an influence on policy choices' towards the audiovisual sector (Papathanassopoulos and Negrine, 2011: 1). Several EU policy tools have been designed for going hand in hand with the economic transformations of the audiovisual sector and for giving Europe's response to challenges of digitisation, globalisation and commercialisation (d'Haenens, Sousa and Trappel, 2018).

The Television Without Frontiers Directive (TWFD), based on the logic of the 'mandatory liberalization, optional interventionism' (Littoz-Monnet, 2007: 84) was issued in 1989, amended in 1997 and replaced by the Audiovisual Media Services Directive (AVMSD) in 2007. The TWFD established the free flow for television programs and it provided the introduction - only 'where practicable' - of quotas for encouraging the production and distribution of European audiovisual works (Iosifidis, 2011). In other terms, the TWFD was about establishing some minimum common rules and liberalisation (Michalis, 2014). In addition, MEDIA program - established in 1991 - became the key financial instrument in order to support EU audiovisual industries. Today, MEDIA is a part of Creative Europe Program and its annual budget is around 120 million EUR. Comparatively, in 2017, the total budget of French Film Centre (Centre national du cinema) reached 707 million EUR.

It is necessary to bear in mind that the EU policy tools in the audiovisual sector have been built on the tension between market interest and public interest (d'Haenens et al., 2018) and they have constantly struggled between two political logics (Collins, 1994; Gibbons and Humphreys, 2012; Littoz-Monnet, 2007): on the one hand, an interventionist policy model - defended by France, the European film production industry, the Public Service Broadcasters and followed by several countries, such as Spain, Italy, Belgium, Greece and often by the European Parliament. This position highlights the importance of public policies - with financial aid, market regulation, intellectual property rights regulation, protection and promotion of cultural diversity - in audiovisual industries and recognises the specificit of cultural goods and services; on the other hand, an economic regulation model, - defended mostly by private broadcasting lobby, the telecoms industry, the United Kingdom, the Netherlands, Czech Republic, Luxembourg and other northern European countries, as well as by the European Commission (hereafter 'Commission'). This position considers audiovisual goods and services both as industrial sector based on 'free market' norm and as policy area on which the Commission should have reduced competency to intervene.

EU agenda on audiovisual services has been recently dominated by the 2007 AVMSD's review (Vlassis, 2017). Here, the issue was twofold: prevent the 
establishment of formerly local and national standards in digital markets and ensure open audiovisual markets to transnational digital content and/or establish governance arrangements in the digital economy in order to involve large online platforms in the financing, distribution and visibility of European audiovisual content. The new text (Regulation (EU), 2018/1808) - approved by the European Parliament in October 2018 - includes obligations for providers of on-demand audiovisual services to respect a quota of $30 \%$ for European works on their catalogues. Note that during the negotiations on the AVMSD review, several EU Member States, such as France, Spain, Italy, Greece and Romania, proposed the establishment of quota of 30-40\% for European works, whereas Finland, Luxembourg, Denmark, Ireland and Czech Republic were against the perspective of including quotas on the online platforms' catalogues (New Europe, 2018).

In addition, the revised AVMSD includes derogation to the country of origin principle. The latter, seen as cornerstone of European audiovisual policy, means that service providers are only subject to the rules of their country of origin where they are established. According to the revised AVMSD, where Member-States require linear broadcaster and VOD provider, under their jurisdiction, to contribute financially to the production of European and national film content, they may also require linear broadcaster and VOD provider, targeting audiences in their territories, but established in other Member-States, to make such financial contribution (but only in association with the turnover generated in the imposing country).

It can be said that the revised text is based on a logic à la carte, which historically dominates EU intervention in audiovisual industries. It is indicative that in 2019, only France, Germany, Italy, Denmark and the Flemish Community of Belgium have developed obligations for non-domestic providers of on-demand audiovisual media services (Donders et al., 2018: 12).

Second, as for market profile, the EU regulatory policy-making seeks to deal with three key trends in EU film market: (i) the survival of several national film industries and the growth trend of European film production; (ii) the weakness of preventing Hollywood domination in EU audiovisual market; (iii) a strongly fragmented distribution of European films in the internal market.

Tables 1 and 2 highlight that despite a delicate economic environment, EU film production constantly continues to grow. In 2017, the film production almost double compared to 2005 and three countries represent around $50 \%$ of EU film production: France, Germany and Spain. At the same time, US films including

Table I. EU film production (source: EAO).

\begin{tabular}{lllllll}
\hline & 2005 & 2008 & 2011 & 2013 & 2015 & 2017 \\
\hline Total feature films EU28 & $911^{\mathrm{a}}$ & $1,140^{\mathrm{a}}$ & 1,547 & 1,607 & 1,643 & 1,676 \\
\hline
\end{tabular}

${ }^{\mathrm{a}} \mathrm{EU} 27$. 
Table 2. Film production in selected countries (source: EAO).

\begin{tabular}{lllllll}
\hline Feature films produced/year & 2005 & 2008 & 2011 & 2013 & 2015 & 2017 \\
\hline France & 240 & 240 & 271 & 269 & 300 & 300 \\
Germany & 146 & 185 & 205 & 236 & 236 & 247 \\
Spain & 142 & 173 & 200 & 235 & 254 & 247 \\
\hline
\end{tabular}

Table 3. Market share in the EU film market (source: EAO).

\begin{tabular}{llllll}
\hline Market share (in \%)/year & 2009 & 2011 & 2013 & 2015 & 2017 \\
\hline European films & 26.7 & 28.5 & 26.2 & 26.1 & 27.5 \\
US & 67.1 & 61.4 & 69.1 & 64 & 66.2 \\
EU inc./US & 4.2 & 8.4 & 1.1 & 7.3 & 3.7 \\
Others & 2.0 & 1.6 & 3.6 & 2.6 & 2.6 \\
\hline
\end{tabular}

Table 4. National film market share (source: EAO).

\begin{tabular}{llllll}
\hline National film market share (in \%)/year & 2009 & 2011 & 2013 & 2015 & 2017 \\
\hline France & 36.8 & 40.9 & 33.8 & 35.5 & 37.4 \\
Germany & 27.4 & 21.8 & 26.2 & 27.5 & 23.9 \\
Spain & 16 & 15 & 13.9 & 19.2 & 17.0 \\
The Netherlands & 17.3 & 22.4 & 20.5 & 18.7 & 12.0 \\
Sweden & 32.7 & 21.3 & 24.8 & 20.7 & 17.2 \\
\hline
\end{tabular}

those produced in Europe with incoming US investment achieved an estimated market share of $70 \%$. A closer analysis on the European Audiovisual Observatory (EAO) data (European Audiovisual Observatory, 2008-2018) ${ }^{4}$ reveals three points: the European market is characterised by an overwhelming share of Hollywood in the majority of EU members and by an exceedingly small proportion of films from other countries, whereas French film market is marked by a constant and dynamic position of national films (Tables 3 and 4). Moreover, as EAO stressed (Grece, 2016), film theatrical release constitutes key criterion for the film visibility on on-demand services. In a digital world of abundance, theatrical release remains a main way of promoting films.

According to available statistical data, in 2016 EU films travel less well on VOD than US films: on average, EU films are available in 2.8 countries, US films in 6.8 countries. To this it should be added half of EU films are only available on VOD in one country (Grece, 2016: 4). In 2018, European audiovisual content represents $26 \%$ of the available content on VOD services in the EU. British film and TV series titles make up the bulk of EU exports in VOD platforms (Grece and Pumares, 2019). In this regard, while France is historically the leading producer of films in Europe (300 films in 2018, including 118 co-productions), in 2017 , only $1.9 \%$ of 
films available on Netflix in Europe (except France) are French ones (Unifrance, 2018). In a similar vein, in 2018, the US-based companies Netflix and Amazon Prime Video represent $74 \%$ of EU VOD revenues and $79 \%$ of EU VOD subscribers (Grece, 2019). Finally, in France, in 2018 the top-20 most-consumed content on VOD platforms include only two non-US programs - the series La Casa de papel and Black Mirror (Centre national du cinema, 2019: 188).

It is clear here that EU VOD market is characterised by an asymmetry favouring US online platforms and US/anglophone content and a more exhaustive analysis based on consumed content on VOD platforms would not necessarily alter our picture of the balance of power within the European audiovisual landscape.

\section{EU in global audiovisual politics: EI Secreto De Sus Ojos}

The EU, as party to the CDCE, has the formal right to implement the CDCE in the same way as the member-states. The 'European Agenda for culture in a globalizing world', launched by the Commission in 2006 and adopted in 2007 is the first policy framework for culture at EU level. It recognises the EU as a cultural actor in external relations and it claims a leading role for the EU with respect to the CDCE's norms. In 2017, the EU Council adopted the 'Conclusions on an EU strategic approach to international cultural relations' making the promotion of the diversity of cultural expressions a guiding principle in EU external action.

As a result, since 2007, several EU initiatives showed that the EU seeks to promote cultural norms as part of its international economic and cultural relations. It is worth mentioning four types of action: (i) in 2010, UNESCO and the Commission created an expert facility project, funded by the EU in order to implement the CDCE through the strengthening of the system of governance for cultural and audiovisual industries in developing countries; (ii) the inclusion of a 'Protocol on cultural cooperation' in the trade agreements with CARRIFORUM (2008), South Korea (2010) and Central America (2012); (iii) the incorporation of explicit references to the CDCE in the agreements with Ukraine, Moldova and Georgia and in the Comprehensive Economic and Trade Agreement (CETA) between EU and Canada; (iv) the protection - such as in the T-TIP negotiations between EU and US - of the capacity of the Union and its Member-States to implement cultural and audiovisual policies, taking account of developments in the digital environment.

However, the EU strategy has changed in the recent EU trade agreements with Vietnam, Japan and Singapore, finalised between 2016 and 2018. On the one hand, the agreements contain a 'cultural exception' dealing with audiovisual services and incorporated in the Chapter 8 of the agreements devoted to 'Trade in Services, Investment and E-Commerce'. On the other hand, no reference to the CDCE appears in the three agreements and no Protocol on Cultural Cooperation is included. A first reason for this change is related to the international commitments of Japan and Singapore. None of two countries are Parties to the CDCE, while Vietnam ratified the CDCE in 2007. In fact, a more nuanced analysis could lead us 
to two additional factors, which weaken the EU action in global politics for culture.

First, the recent EU initiatives lack social support. As demonstrated by several studies (Loisen and De Ville, 2011; Garner, 2017; Vlassis, 2016a), he mentioned initiatives illustrate a top-down approach without clear links to the European organisations of cultural professionals. The top-down building of the Protocols on Cultural Cooperation - based on Commission's initiative - hinders effective implementation of their provisions, leaving aside the main actors of the implementation, such as EU national governments and EU culture organisations (European Centre for Development Policy Management, 2011; European Commission, 2014).

Second, the balance between intergovernmentalism method and Community action leads to another factor (Ang et al. 2015; Vlassis, 2016a). Clearly, the relationship between Commision and several national governments, such as French authorities, is based on a constant suspision related to the treatment of cultural goods and services in trade agreements. During the negotiations on T-TIP, the Commission sought to include the digital cultural services in the EU mandate of negotiations, questioning explicitly the 'cultural exception' norm. Even José Manuel Barroso, president of the Commission, characterised cultural exception as a 'reactionary and harmful position' (Le Monde, 2013). Moreover, the Protocol on Cultural Cooperation with South Korea was strongly criticised by French government. The latter denounced that the Commission intended to include the cultural and audiovisual industries within the agenda of negotiations in order to use them as a selling point for proceeding with trade deals and gain concessions in other economic areas (Vlassis, 2016a).

It is revealing that in 2017, under the instigation of France and Canada, the Parties to the CDCE adopted Operational Guidelines in order to align the CDCE with the development of digital technologies. Even though the EU is Party to the Convention, it did not participate in the UNESCO debates on the operational guidelines as a single entity due to lack of common European position on the link between cultural industries and digital technologies.

\section{EU in the global film market: For a few dollars more}

Despite these several developments, the balance of power within the global film market is constantly characterised by a strong asymmetry in favour of the United States. In other terms, EU could not be regarded as a global or even regional power in global film market. The European film market is still an integrated feature of the US economy. Inspired by the world system theory of the French historian Fernand Braudel, the economist Charles-Albert Michalet pointed out that since 1980s, Hollywood has developed the 'world-cinema' (cinema-monde) strategy based on three key mechanisms: (i) the development of world movie, both an event and a global film; (ii) the development of a global approach on the market; (iii) the establishment of a horizontal cooperation among companies centred on entertainment activities. 'The world cinema reflects the economic forces that showed up the 
global capitalism, namely an economic system that can only be operating in a global dimension' (Michalet, 1987: 112).

The fact of Hollywood's domination of global trade in motion pictures is well established (Miller et al., 2005; Scott, 2005) and the following comparative data add further gloss on the worldwide market power of Hollywood. Despite normative developments about film industry previously mentioned, during the period 2012-2018, the 15 highest film successes, distributed by Hollywood studios, represent about a third of annual worldwide cinema revenues: in 2012, they accumulate about $34 \%$ of revenue in the global marketplace, $32 \%$ in $2013,30 \%$ in $2014,37 \%$ in $2015,32 \%$ in $2016,34 \%$ in 2017 and $33 \%$ in 2018. An additional point is that in 2013, 2015 and 2017, the 15 highest movie successes, distributed by Hollywood, recorded more than half of their revenues within 'international' cinema markets outside the United States and Canada. ${ }^{5}$

Moreover, the Hollywood majors have a strong capacity of strategic adaptation to new technological forces. This claim is confirmed by three recent economic alliances: first, the acquisition by the telecommunication company AT\&T of entertainment conglomerate Time Warner - including film studio Warner Bros. and cable-satellite television network HBO; second, the acquisition by the Walt Disney Company of the film studio 20th Century Fox and of the VOD service Hulu. Main result of these acquisitions is the launch of two new global VOD platforms: HBO Max and Disney+. Third, in January 2019, Netflix became the first internet company-VOD platform to join the ranks of Motion Pictures Association of America, granting membership to the trade association.

Furthermore, despite the spread of 'cultural exception' norm in the 1990s and the dynamic implementation of CDCE since 2005, Hollywood film, enjoying major technological developments, has remained a key content for several media platforms (DVD, TV and VOD). The comparative data between US, Chinese, Indian and EU movies presented in Tables 5, 6, 7 and 8 illustrate that Hollywood movies are still the only global audiovisual content.

First, the Chinese film market is characterised by impressive growth. In 2004, total film market revenues represent 435 million USD. By contrast, in 2019, Chinese film market is one of the 'few large enough to compete with that of the United States' (Overpeck, 2018: 27), generating 9.2 billion USD in box-office revenue - 20 times higher than 15 years ago. Due to strict regulatory mechanisms high quotas for national content, distribution restrictions, censorship ( $\mathrm{Su}, 2016$; Vlassis, 2016b) -, Chinese film keeps achieving an estimated national market share of $50 \%$. Yet, Chinese films are particularly made in order to satisfy the impressive expansion of national film market, whereas Chinese cinema is not on the point of breaking out beyond its established market sphere. As such, Chinese movies achieve extremely poor results in a few film markets and they are not on release in the majority of countries in Asia, Europe and Latin America (Table 6).

Second, Tables 5 and 8 reveal the overwhelming gap between Hollywood movies and Indian cinema in international markets, as well as the weakness of Indian film industry to export more dynamically. Indian movies are notably made 


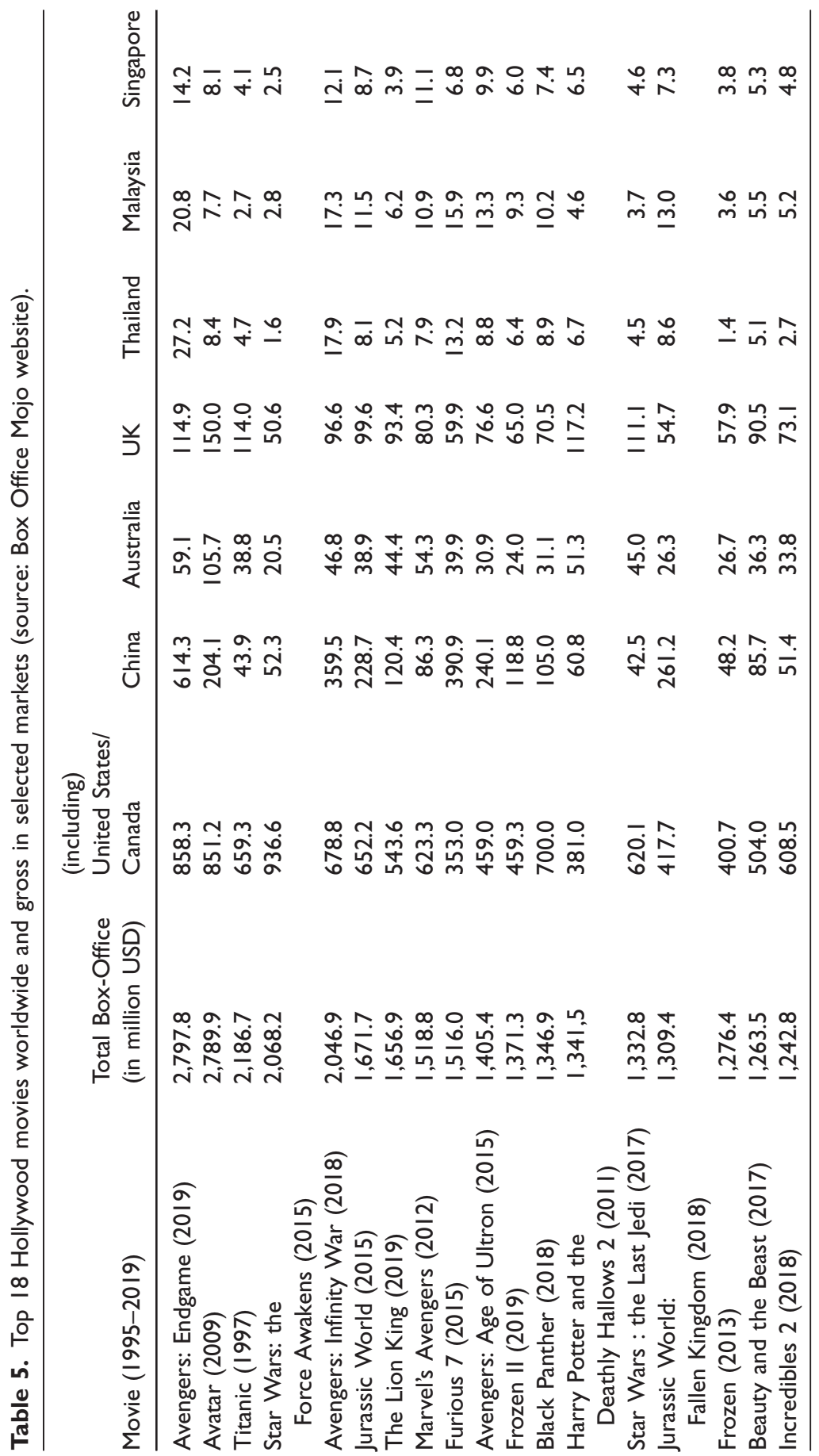




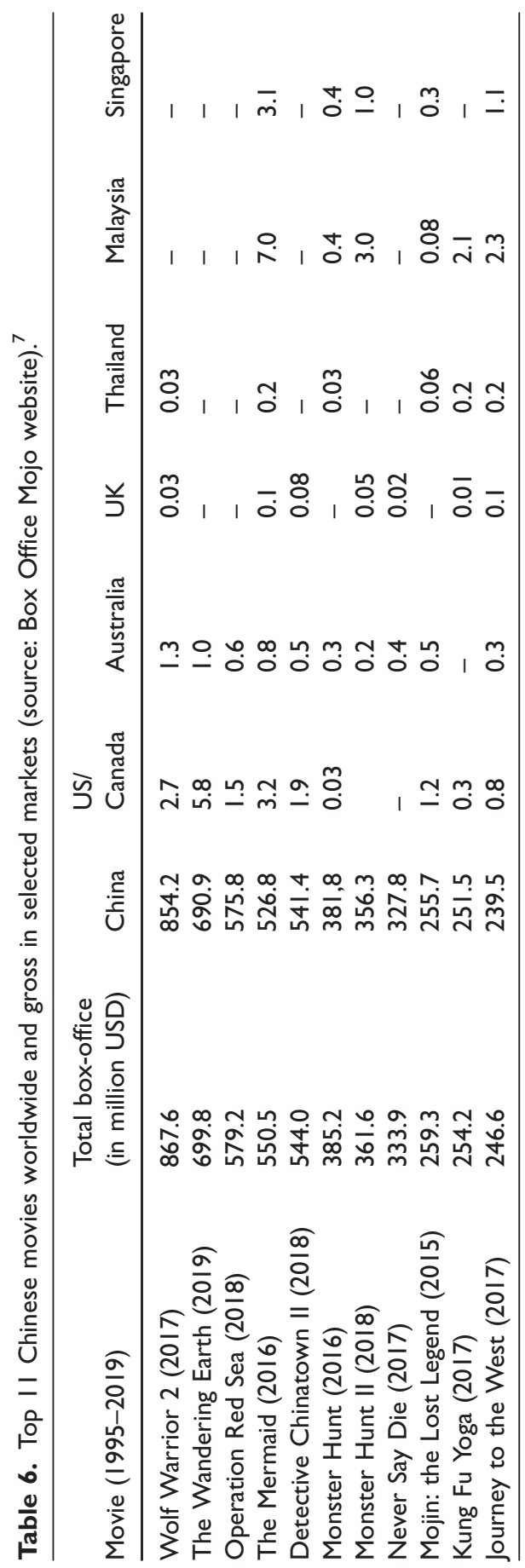




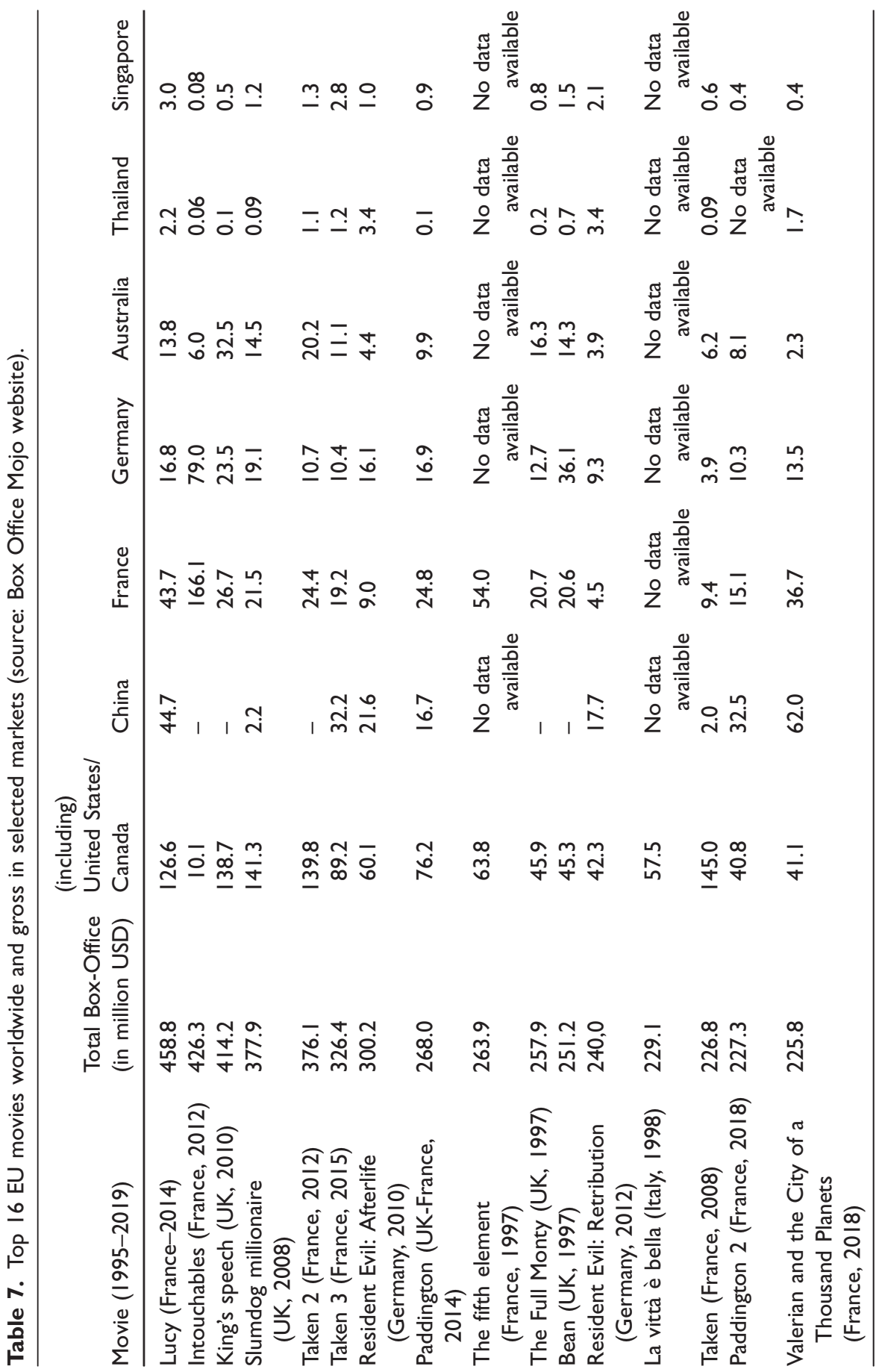




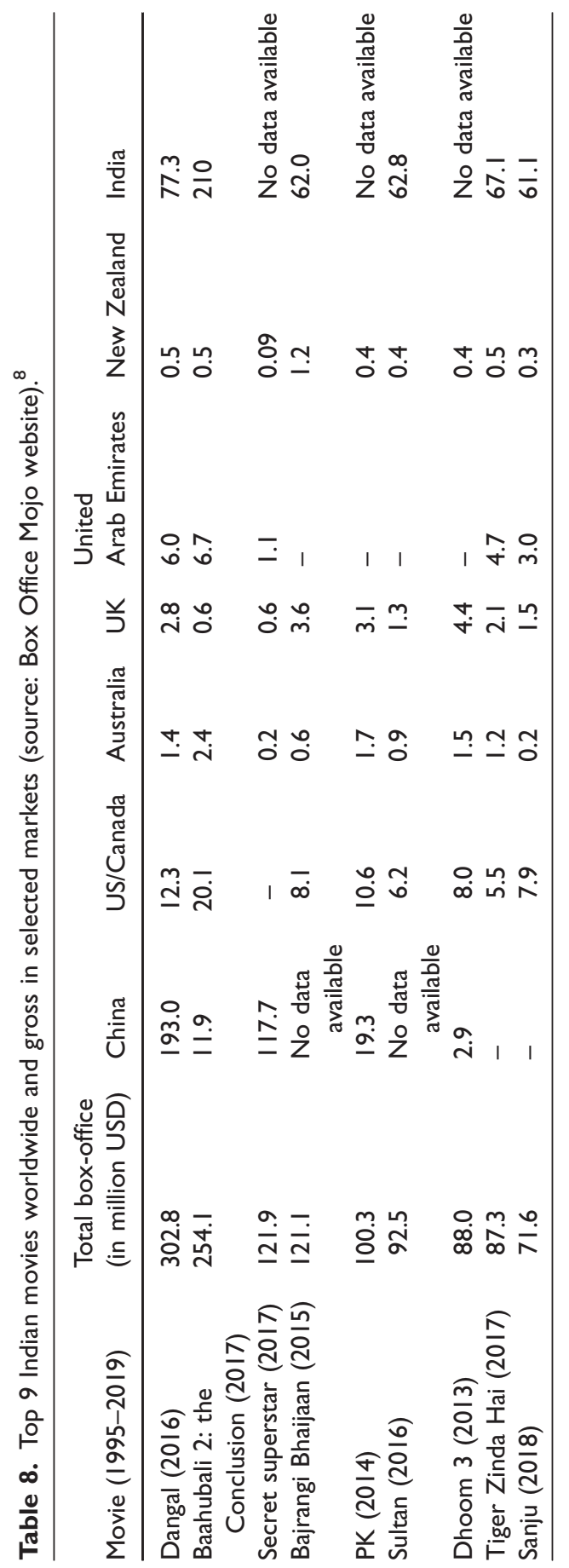


for the domestic market and only few number of movies achieve good results in other national film markets, especially in China.

Third, Table 7 on the Top 16 EU movies - UK movies included - worldwide reveals that European audiovisual industry is on the point of making some films with high production values and a relatively appeal to global audiences, having the ability to penetrate well beyond its usual range of trade. However, three important findings should be highlighted here: (i) except La Vità è bella, all the movies are produced in France, Germany and in the UK; (ii) except Intouchables and La Vità è bella, all these movies are anglophone and (iii) 7 out of 16 movies movies are produced by the same French producer and film-maker, Luc Besson, who since 1990s has moved 'towards popular genres and narratives previously considered the domain of Hollywood' (Bergfelder, 2005: 318).

In this view, it can be said that there is still a small number of centres of motion picture production around the world, such as EU, India, China-Hong Kong, South Korea or Japan, that maintain high levels of output in terms of films made by year. Simultaneously, financial and regulatory measures for film sector succeed to maintain and to promote a thriving national film industry such as in France, South Korea or China (European Audiovisual Observatory, 2008-2018). However, all these alternative sites of film production fail to challenge the dominance of Hollywood in terms of global visibility, unparalleled marketing capacity and worldwide distribution (Crane, 2014; Vlassis, 2016b). As such, the comparative statistical data presented here highlight the unprecedented capacity of Hollywood in terms of worldwide film distribution. Indeed, the 'world-cinema' strategy contributes to increase the imbalance within global film market and to establish Hollywood's domination in two directions: it is used for limiting the access to the US market for foreign movies, which do not enjoy major financial and marketing resources; on the other side of the coin, following the same logic, the 'world-cinema' mechanisms grant the advantage to Hollywood movies in the global trade in motion pictures entailing progressive economic integration of national film markets and convergence of audience's time and preferences (Vlassis, 2016b).

These remarks lead the discussion directly to the fact that the launch of disruptive US VOD services - such as Netflix, Amazon Prime Video, HBO Max, Apple TV Plus or Disney+ - and the attempted export of these services to global markets (Jin Dal, 2017; Lobato, 2018) follow the mechanics of 'world-cinema'. These online platforms have unequalled capacities to disseminate audiovisual content on a global scale and exercise strong influence over whether and how audiovisual content can be accessed, even though these VOD services are expected to have 'differentiated effects on the markets' they have entered (Lobato, 2018: 184). Today the only worldwide VOD services are US-based companies, such as Netflix and Amazon Prime Video - and by end 2020 we should add HBO Max, Disney+ and Apple TV Plus: Netflix, the world's largest subscription VOD service, is available worldwide except mainland China, Syria, North Korea. As of February 2020, Netflix has around 170 million total subscribers worldwide and it spent around 
12 and 15 billion USD on original content in 2018 and 2019, respectively. For its part, Amazon Prime Video has around 100 million subscribers and it launched worldwide in December 2016 except for mainland China, Cuba, Iran, North Korea and Syria.

Here, the case of China is representative about potential change of audiovisual content flow due to the trend of platformisation. As of February 2020, Netflix, Amazon Prime Video and other foreign VOD services are blocked for operating in mainland China under Internet censorship policy, leaving plenty of room for encouraging national private investment and strengthening Chinese VOD services. The three Chinese Internet giants Baidu, Alibaba and Tencent (collectively known as BAT) have been expanding in the entertainment sector (Meng, 2018: 95), setting up VOD platforms. In this respect, foreign streaming giants are missing out and China's fast-growing VOD market ${ }^{6}$ is currently dominated by three platforms operated by BAT - Baidu's iQiyi, Alibaba's Youku and Tencent's Tencent Video. Chinese authorities restrict national VOD companies to ensure that no more than $30 \%$ of their content emanates from overseas. Search for US audiovisual content was a direct effect of banning foreign VOD services and in this regard, content licensing deals have strongly been multiplied:

(i) in September 2013, Tencent Video signed a deal with Disney Media Distribution to bring a collection of Disney, Pixar and Marvel Studios titles to the company's streaming movie service;

(ii) Tencent became in November 2014 the HBO's exclusive online partner in China;

(iii) in September 2015, Paramount Pictures signed content licencing deal with Youku, the Alibaba's video streaming player, for more than 100 titles from the Paramount film library;

(iv) Warner Bros signed a deal to supply movies to iQiyi in March 2017;

(v) Netflix introduce original content in China via a licensing deal signed in April 2017 with iQiyi;

(vi) in December 2017, Youku signed content licencing deal with NBCUniversal and Sony Pictures Television.

Indeed, the dominance of BAT in the national VOD market is strongly based on strict regulation from Chinese authorities, which ban the activities of foreign streaming giants. In other terms, VOD market seems to be a mirror of the Chinese film market: impressive domestic expansion of the VOD market; encouragement of national private investment; strong presence of Chinese and US audiovisual content. By contrast, the activities of the three Chinese VOD platforms are poor beyond the mainland China. As stated by Y. Weidong, president of Youku, 'by cooperating with NBCUniversal and Sony Pictures Television to show famous Hollywood films on our platform, we can bring richer global content into Alibaba's entertainment ecosystem' (South China Morning Post, 2017). 
Lastly, with these remarks in mind, it has to be said that since the arrival of Trump administration, the US trade diplomacy become more transactional, unilateral and offensive in its use of trade defence instruments. The new US priorities could have an impact on worldwide audiovisual content flow, insofar as over the last 30 years, US FTAs have been a key tool for eliminating foreign trade barriers in audiovisual content flows. It is revealing that China and the US are currently negotiating an eight-year old agreement dealing with film industry. The negotiations were initially planned to be concluded by the end of 2017. That did not happen due to Trump administration's decisions to impose tariffs on several Chinese goods and services.

\section{Concluding remarks}

The article has offered a first multi-dimensional investigation in order to highlight the EU influence in global audiovisual politics and economy, paying special attention to the nexus between 'audiovisual industry and online platforms' and analysing whether the EU practices are translated into impact in the global film economy. As such, by exploring the continuity in a context of major technological developments, the article provided a deeper understanding of the balance of power and its transformations in the global audiovisual politics and economy. The picture that emerges sheds light on seven key points:

First, global audiovisual politics are based on a normative dichotomy between 'free trade' norm, which favours the breaking down of regulatory and financial measures in the audiovisual sector as prominent conditions of development for this industry on one side, and on the other side, the 'cultural exception' norm, which recognises the importance of cultural policies and the specificity of cultural goods and services. This dichotomy has been established beyond international political cleavages, such as North/South divide or West/the Rest. Today, the context of platformisation intensifies the existing political debate, insofar as online platforms offer innovative ways of providing audiovisual content over electronic networks, challenging strongly the 'cultural exception' norm.

Second, the major issue in the EU is related to the regulation of the digital audiovisual economy in order to involve the large online platforms in the financing, distribution and visibility of European audiovisual content. Indeed, the adopted measures follow path-dependence logic from the analogue-broadcast era to the digital one. On the one hand, the EU response is based on a logic à la carte, which historically dominates the EU governance in audiovisual industries. On the other hand, today several EU member states are seeking to re-balance the rules of audiovisual ecosystem between traditional players in the sector, such as TV channels and cinema theatres, subject to several obligations and new digital players, such as online platforms. There is also strong possibility that some EU member-states could pursue their efforts, aiming to establish more ambitious audiovisual legislations in terms of obligations for online platforms and to promote actively their cultural sovereignty online. 
Third, since the CDCE adoption, the EU has sought to include the diversity of cultural expressions among its priorities, especially using trade agreements as main way to transpose cultural norms. As such, despite some political divisions, EU seeks to promote 'cultural exception' norm in trade agreements, taking account of developments in the digital environment. However, EU initiatives in promoting cultural norms to global governance of trade and investment face both lack of social support from organisations of cultural professionals and reluctance of member states with strong interests in cultural affairs.

Fourth, despite these policy developments, Hollywood majors continue to play a dominant role in global audiovisual economy and EU is not still regarded as a global or even regional power in global trade in motion pictures. That being said, even though financial and regulatory measures represent forms of surviving and maintaining a national cinematography such as the cases of France or South Korea, they fail to challenge the Hollywood's domination in terms of marketing capacity and worldwide distribution.

Fifth, small wonder, then, that the powerful US VOD services - engaged in internationalising their activities and building synergistic strategies - follow the 'world-cinema' strategy. Despite their competition with each other, US online platforms - such as Netflix, HBO Max, Disney+, Amazon Prime Video and Apple TV Plus - are connected by common audiovisual language and strong strategic interdependence, benefitting from large domestic base of consumers, economies of scale, popularity of English speech and capacity of producing in multiple languages. In the light of this situation, US platforms also contribute to the progressive economic integration of national audiovisual markets and to the dynamic convergence of audience's time and preferences. As such, the recent activities of US online platforms and the alliances between large online platforms and Hollywood majors endow the US audiovisual industry with further competitive capacities in its long-term ascendancy on world audiovisual content flows.

Sixth, the controversial discussions around 'cultural exception' and 'diversity of cultural expressions' showed that the US have no longer the uncontested normative and moral leadership (Tunstall 2008) in global audiovisual politics. Besides, online platforms have not resolved political tensions but they seem to intensify existing political dichotomies. Today, there is possibility of stricter regulation and higher quotas online, notably in some EU member-states. However, recent regulatory developments have not significantly altered the balance of power in global audiovisual landscape and the arrival of powerful US VOD platforms largely strengthens the remarkable durability of Hollywood/US content as central point of reference in the global audiovisual economy.

Finally, the US unilateral trade diplomacy could have an impact on global audiovisual economy. It is rather complex to assess today the effects of the rising trade conflicts on worldwide audiovisual and film flows. But, there is strong possibility to lead to more ethnocentric and closed audiovisual markets slowing down the worldwide expansion of US audiovisual content rather than to the rise of global challengers to US audiovisual dominance. 


\section{Acknowledgement}

An earlier version of this article was presented at the International Conference on 'The EU and its Partners in Global Governance: Trade, Investment, Tax and Sustainable Development', Hong-Kong, 14-15 June 2018. The conference was organized in the framework of the Jean Monnet Network 'The European Union at the Crossroads of Global Order (EUCROSS)'.

\section{Declaration of Conflicting Interests}

The author(s) declared no potential conflicts of interest with respect to the research, authorship, and/or publication of this article.

\section{Funding}

The author(s) received no financial support for the research, authorship, and/or publication of this article.

\section{Notes}

1. The statistical data presented in the article come from European Audiovisual Observatory, Box Office Mojo, IMDb, Centre national du Cinema (CNC-France), Motion Pictures Association of America (MPAA).

2. Australia, Bahrein, Chile, Colombia, Costa-Rica, Dominican Republic, Guatemala, Honduras, Jordan, Morocco, Nicaragua, Oman, Panama, Peru, Salvador, Singapore, South Korea.

3. Australia, Brunei, Canada, Chile, Japan, Malaysia, Mexico, New Zealand, Peru, Singapore, US and Vietnam.

4. Our conclusions are based on the statistical data from European Audiovisual Observatory. See also Tables 1-4. https://www.obs.coe.int/en/web/observatoire/.

5. Author's research results based on MPAA and Mojo statistical data.

6. According to Statista, revenue in the Chinese VOD market amounts to 1.73 billion USD in 2018 compared to 0.93 billion USD in 2016. https://www.statista.com/outlook/201/ 117/video-on-demand/china.

7. Available comparative statistical data only regarding these 11 Chinese movies.

8. Available comparative statistical data only with respect to these nine Indian movies.

\section{ORCID iD}

Antonios Vlassis (D) https://orcid.org/0000-0003-3787-4425

\section{References}

Ang I, Isar YR and Mar P (2015) Cultural diplomacy: Beyond the national interest? International Journal of Cultural Policy 21(4): 365-381.

Bergfelder T (2005) National, transnational or supranational cinema? Rethinking European film studies. Media, Culture \& Society 27: 315-331.

Buchsbaum J (2017) Exception Taken: How France has Defied Hollywood's New World Order. New York: Columbia University Press. 
Canedo D and Crusafon C (2014) The European audiovisual policy goes abroad: The case of inter-regional cooperation with Mercosur. In: Donders K, Pauwels C and Loisen J (eds) The Palgrave Handbook of European Media Policy. London: Palgrave Macmillan, pp. 526-541.

Centre national du cinéma (2019) Bilan 2018. Paris: CNC. Available at: https://www.cnc.fr/ documents/36995/153434/CNC_Bilan_2018.pdf/f97eb201-5bce-38b0-3b1d190377 f4bef8.

Collins R (1994) Broadcasting and Audiovisual Policy in the European Single Market. London: John Libbey.

Council of the European Union (2019) The negotiating directives for the Doha Development Agenda regarding the plurilateral negotiations of rules and commitments on electronic commerce. Brussels 8993/19, ADD 1, 20 May.

Crane D (2014) Cultural globalization and the dominance of the American film industry: Cultural policies, national film industries, and transnational film. International Journal of Cultural Policy 20(4): 365-382.

Deloumeaux L (2018) Persisting imbalances in the flow of cultural goods and services. In: UNESCO (ed) Re-shaping Cultural Policies: Advancing Creativity for Development. Paris: UNESCO, pp. 125-142.

D’Haenens L, Sousa H and Trappel J (2018) Comparative Media Policy, Regulation and Governance in Europe: Unpacking the Policy Cycle. Bristol: Intellect.

Donders K, et al (2018) Obligations on On-demand Audiovisual Media Services Providers to Financially Contribute to the Production of European Works: An Analysis of European Member States' Practices. Brussels: Vrije Universiteit Brussel.

European Audiovisual Observatory (2008-2018) Focus: World Film Market Trends. Strasbourg: European Audiovisual Observatory.

European Centre for Development Policy Management (2011) Implementing cultural provisions of Cariforum-EU EPA, How do they benefit the Caribbean cultural sector? Discussion paper 118, 1 June.

European Commission (2014) Proposal for a council decision on the position to be taken on behalf of the European Union as regards the extension of the entitlement to co-productions as provided for in Article 5 of the protocol on cultural cooperation to the FTA between the EU and its member states, of the one part and the Republic of Korea, of the other part. COM (2014). Brussels: European Commission 81 final, 18 February.

Evens T and Donders K (2018) Platform Power and Policy in Transforming Television Markets. London: Palgrave Macmillan.

Gagné G (2016) The Trade and Culture Debate: Evidence from US Trade Agreements. New York: Lexington Books.

Galperin H (1999) Cultural industries policy in regional trade agreements: The cases of NAFTA, the European Union and MERCOSUR. Media, Culture \& Society 21: 627-648.

Gibbons T and Humphreys P (2012) Audiovisual Regulation under Pressure: Comparative Cases from North America and Europe. London: Routledge.

Garner B (2017) Towards a European strategy on culture and development: Learning from the CARIFORUM-EU Economic Partnership Agreement. Politique européenne 56: $146-168$. 
Graber CB (2006) The new UNESCO convention on cultural diversity: A counterbalance to the WTO? Journal of International Economic Law 9(3): 553-574.

Grece C (2016) How do Films Circulate on VOD Services and in Cinemas in the European Union? Strasbourg: European Audiovisual Observatory.

Grece C (2019) Trends on the EU VOD market. A presentation of the European Audiovisual Observatory, 3 September.

Grece C and Pumares MJ (2019) Film and TV Content in VOD Catalogues. Strasbourg: European Audiovisual Observatory.

Guèvremont V (2015) Promoting the Convention in international forums. In: UNESCO (ed) Re-shaping Cultural Policies: A Decade Promoting the Diversity of Cultural Expressions for Development. Paris: UNESCO, pp. 143-161.

Harvey D (2005) A Brief History of Neoliberalism. Oxford: Oxford University Press.

Iosifidis P (2011) Global Media and Communication Policy. London: Palgrave Macmillan.

Jin Dal Y (2017) Digital platforms as a double-edged sword: How to interpret cultural flows in the platform era. International Journal of Communication 11: 3880-3898.

Le Monde (2013) Exception culturelle: les propos de Barroso provoquent un tollé. 17 June.

Littoz-Monnet A (2007) The European Union and Culture: Between Economic Regulation and European Cultural Policy. Manchester: Manchester University Press.

Lobato R (2018) Netflix Nations: The Geography of Digital Distribution. New York: New York University Press.

Loisen J and De Ville F (2011) The EU-Korea protocol on cultural cooperation: Toward cultural diversity or cultural deficit? International Journal of Communication 5: 254-271.

Mansell R (2015) Platforms of power. Intermedia 43(1): 20-24.

Meng B (2018) The Politics of Chinese Media: Consensus and Contestation. London: Palgrave Macmillan.

Michalet CA (1987) Le drôle de drame du cinéma mondial. Paris: La Découverte.

Michalis M (2014) Focal points of European media policy from inception till present: plus ça change? In: Donders K, Pauwels $\mathrm{C}$ and Loisen $\mathrm{J}$ (eds) The Palgrave Handbook of European Media Policy. London: Palgrave Macmillan, pp. 128-142.

Miller T and Yúdice G (2002) Cultural Policy. London: SAGE.

Miller T, et al. (2005) Global Hollywood 2. London: British Film Institute.

MPAA (2017) MPAA Comments on the National Trade Estimate Report on Foreign Trade Barriers. Washington: MPAA.

New Europe (2018) EU institutions strike preliminary 30\% quota deal on Netflix-like providers. Brussels, 1 May.

Nieborg D and Poell T (2018) The platformisation of cultural production: Theorizing the contingent cultural commodity. New Media \& Society 20(11): 4275-4292.

Overpeck D (2018) Monitored relations: The US film industry, Chinese film policy and soft power. In: Mingant N and Tirtaine C (eds) Reconceptualising Film Policies. London: Routledge, pp. 27-40.

Papathanassopoulos S and Negrine R (2011) European Media: Structures, Policies and Identities. Cambridge: Polity.

Pauwels C and Loisen J (2016) Leading by example? European Union implementation of cultural diversity in internal and external audiovisual policies. Javnost-The Public 23(2): 153-169.

Psychogiopoulou E (2014) The external dimension of EU cultural action and free trade: Exploring and interface. Legal Issues of Economic Integration 41(1): 65-86. 
Richieri-Hanania L (2019) European Union Trade Agreements and cultural exception in the digital age. In: Albornoz L and Garcia Leiva T (eds) Audio-visual Industries and Diversity: Economics and Policies in the Digital Era. London: Routledge, pp. 136-151.

Sarikakis K and Ganter S (2014) Priorities in global media policy transfer: Audiovisual and digital policy mutations in the EU, MERCOSUR and US triangle. European Journal of Communication 29(1): 17-33.

Scott AJ (2005) On Hollywood: The Place, the Industry. Princeton: Princeton University Press.

South China Morning Post (2017) Chinese video platform Youku signs licensing deals with NBC Universal, Sony Pictures TV. 14 December. Available at: https://www.scmp.com/ tech/enterprises/article/2124282/chinese-video-platform-youku-signs-licensing-dealsnbc-universal.

Srnicek N (2017) Platform Capitalism. Cambridge: Polity Press.

Su W (2016) China's Encounter with Global Hollywood: Cultural Policy and the Film Industry 1993-2014. Lexington: University Press of Kentucky.

Thorsby D (2010) The Economics of Cultural Policy. Cambridge: Cambridge University Press.

Tunstall J (2008) The Media Were American: U.S. Mass Media in Decline. New York and Oxford: Oxford University Press.

UNESCO Institute for Statistics (2016) The Globalization of Cultural Trade: A Shift in Consumption: International flows of cultural goods and services 2004-2013. Montreal: UNESCO-UIS.

Unifrance (2018) Indicateur VOD 2018: Étude sur la place des films français en VoD sur iTunes et Netflix en Europe. Paris: Unifrance.

Vlassis A (2015) Gouvernance mondiale et culture: de l'exception à la diversité. Liège: Presses universitaires de Liège.

Vlassis A (2016a) European Commission, trade agreements, and diversity of cultural expressions: Between autonomy and influence. European Journal of Communication 31(4): 446-461.

Vlassis A (2016b) Soft power, global governance of cultural industries and rising powers: The case of China. International Journal of Cultural Policy 22(4): 481-496.

Vlassis A (2017) The review of Audiovisual Media Services Directive: Many political voices for one digital Europe? Politique européenne 56: 102-123.

Vlassis A (2018) Partenariats transrégionaux, technologies numériques et culture: de la convergence numérique aux divergences normatives. In: Deblock $\mathrm{C}$ and Lebullenger $\mathbf{J}$ (eds) Génération TAFTA: les partenariats commerciaux à l'ère de l'interconnexion. Rennes: Presses Universitaires de Rennes, pp. 211-223.

Vlassis A, Rioux M and Tchéhouali D (2020) La culture à l'ère du numérique: plateformes, normes et politiques. Liège: Presses Universitaires de Liège. 